ORIGINAL ARTICLE

\title{
Several Factors Associated with Nitrogen Balance in Elderly Patients
}

\author{
Zurriyani $^{1}$,Jusri Ichwani2*, Novira Widajanti ${ }^{2}$ \\ ${ }^{1}$ Department of Internal Medicine, Faculty of Medicine, Universitas Airlangga - Dr. Soetomo General Hospital Surabaya, \\ Indonesia. \\ ${ }^{2}$ Division of Geriatrics, Department of Internal Medicine, Faculty of Medicine, Universitas Airlangga - Dr. Soetomo \\ General Hospital Surabaya, Indonesia.
}

\begin{abstract}
A B S T R A C T
Background: Nitrogen balance is the method used to assess the protein adequacy. A negative nitrogen balance means that the body suffers from protein energy malnutrition.

Objective: To determine the risk factors that associated with nitrogen balance in the elderly patients who were inpatient in IRNA Internal Medicine Dr. Soetomo General Hospital Surabaya.

Methods: The experimental design of the research used was analytic observational with the cross-sectional design. The study was conducted of 50 elderly patients. Risk factors measured were protein intake using food recall and nitrogen excretion that expressed in Urea Nitrogen Urine ( $\mathrm{gr} / 24 \mathrm{~h}$ ). The nitrogen balance was derived from the difference between nitrogen intake and nitrogen excretion in 24 hours. Bivariate data analysis using Chi square or exact fisher test, while multivariate data analysis using logistic regression test.

Results: In bivariate analysis, risk factors significantly associated with negative nitrogen balance were decreased renal function (LFG $<90 \mathrm{ml}$ $/ \mathrm{min} / 1.73 \mathrm{~m} 2$ ), prolonged bed rest $>7$ days and malnutrition. Other risk factors not significantly associated with negative nitrogen balance were diabetes mellitus, random blood sugar $>180 \mathrm{mg} / \mathrm{dl}$, hypoalbumin and CRP> $6 \mathrm{mg} / \mathrm{dl}$. In multivariate analysis showed the decrease of renal function and duration of bed rest $>7$ days was significant.
\end{abstract}

Conclusion : The decreased renal function and bed rest for more than 7 days was a risk factor for protein malnutrition in elderly patients.

Keywords: Nitrogen Balance, Protein Malnutrition, LFG, Prolonged Bed Rest, Kidney

Correspondence: Jusri Ichwani

E-mail: Jusri_ichwani@yahoo.com

Article history: • Received 20 December $2019 \bullet$ Received in revised form 07 January $2020 \bullet$ Accepted 16 January 2020

\section{INTRODUCTION}

The nitrogen balance is the method used to assess the adequacy of proteins by looking at the difference between the amount of nitrogen that enters the body each day (especially from the food protein) and the amount of nitrogen that passes through urine, sweat, stool also through miscellaneous such as loss through the epidermis (sweating) (Lieberman et al., 2007).

The balance of nitrogen in healthy adults is zero, i.e., the amount of nitrogen obtained from food is equivalent to the amount that comes out. If the nitrogen that comes out more than obtained from food there will be a negative nitrogen balance. On the contrary, if more nitrogen enters than exit there is a positive nitrogen balance. Nitrogen is an excellent marker for determining protein adequacy because $95 \%$ of the body's nitrogen describes body protein levels (Lieberman et al., 2007, Smil, 2002).

Geriatric patients are patients of different characteristics with younger age, ie with multipath ology such as mental disorders/cognition, nutritional disorders, functional status disorders, and other chronic diseases(Musso and Núñez, 2006). These conditions cause geriatric patients often experience nitrogen balance disorder, sometimes unknown so the nutritional needs are not met (Brownie, 2006).
An ongoing negative nitrogen balance will increase morbidity, decreased functional status, immune dysfunction, decreased cognitive function, long wound healing/delayed recovery of the surgical wound, high rates of hospitalization and treatment also even double death rates of malnutrition compared with no malnutrition (Rubenstein et al., 2001, Morais et al., 2006, Ahmed and Haboubi, 2010, Carrero et al., 2013).

Factors that causing the negative nitrogen balance disorder falls in malnutrition conditions are due to lack of optimal long-term protein intake, various diseases that affect old age, cognitive decline, disturbed tooth condition, isolation, poverty, fractures, heart failure, impaired renal function, duration of bed rest (immobility), endocrine disorders such as diabetes mellitus, surgery, trauma, burns or even drugs (Epel, 2009, Kurpad and Vaz, 2000, Kagansky et al., 2005, Smoliner et al., 2008).

Studies conducted by Pannemans et al. (1997) in the elderly by measuring the balance of nitrogen concluded that there was no significant difference between low protein intake and high protein intake (Pannemans et al., 1997). This is in contrast to previous studies that negative nitrogen balance occurs due to low protein intake. The difficulty of achieving nitrogen balance in old age is not 
only due to protein intake, but also influenced by stressful conditions such as chronic infections and diseases and socioeconomic factors (Kurpad and Vaz, 2000). The aims of this study was to determine the factors that affect the balance of nitrogen in the elderly so it is expected to be done intervention nutritional therapy in elderly patients to prevent the occurrence of malnutrition, and could be used as a basis in calculating the adequacy of protein in old age.

\section{METHODS}

The population of this study was elderly patients who were admitted to the Inpatient Medical Installation of Internal Medicine of Dr. Soetomo General Hospital on April to July 2014. The samples were taken using the consecutive sampling method that met the following criteria: age $>60$ years, male and female, were being hospitalized in IRNA's Medical Internal Medicine room with immobility, diabetes mellitus, impaired renal function, malnutrition/reduced intake and inflammation/sepsis, and were willing to follow the research and have signed informed consent.

On the other hand, we excluded the patients with hepatic cirrhosis, cancer, trauma, burns, surgery and delirium. While, the other exclusion criteria were includes patients taking anabolic hormone testosterone (and its analogue), insulin-like growth factor (IGF-I), growth hormone $<2$ times half-life and steroid (dexamethasone, methylprednidolon, hydrocortison, etc.) time $<2$ times half-life.

Patients who were hospitalized in IRNA Medical Science of Internal Medicine RSU Dr. Soetomo measured the protein intake for 24 hours through a food record or in 24-hour food recall form with the assumption that the intake of nitrogen was intake protein (gram) / 24 hours / 6.25. The intake of food consumed will be monitored by researchers and nutrition officers of each room.

Nitrogen output will be measured through Urea Nitrogen from urine contained that 24 hours later will be examined using enzymatic calorimetry. The measured were done by Cobas 501 with urease - GLDH / UV kinetic method. Nitrogen balance was measured using the following formula:

Nitrogen balance $=$ nitrogen intake $(g r / 24 h)$ - urine nitrogen $(g r / 2 h)+4(g r / 24 h)$

Nitrogen balance expressed in units of grams / 24 hours was the data with the ratio scale. The result of the balance of nitrogen +4 to +6 means anabolism occurs, the value of +1 to -1 means that the nitrogen balance was reached while the value $<-1$ means the occurrence of catabolism. It also measured other factors that could affect the nitrogen balance of diabetes mellitus measured by random blood sugar (GDA), glomerular filtration rate (LFG), mini nutritional assessment (MNA) score, albumin, C-reactive protein (CRP) and duration of bed rest.

The data were analyzed by using bivariate analysis with Chi-square test and cross tabulation method if it qualified then using Fisher test if not qualified to determine the relationship between one variable with another variable. The independent variables were found to have a significant relationship $(\mathrm{p}<0.025)$ with nitrogen balance, then tested by multivariate analysis that was logistic regression test to determine the contribution and the value of odds ratio (OR) with value $p<0.05$ indicates the significant relationship. Multivariate analysis was conducted to determine the relationship/influence of some independent variables with a dependent variable simultaneously. Data analysis was using SPSS software version 21.

\section{RESULTS}

The total number of samples that meeting the inclusion criteria were 50 subjects aged over 60 years. The number of males and females were $27(54 \%)$ and $23(46 \%)$ respectively with mean age of 69.88 years (Table 1$)$.

Table 1. The General Characteristics of Research Subjects

\begin{tabular}{|c|c|c|c|c|}
\hline Characteristics & Frequency & Mean & $\begin{array}{l}\text { Standard } \\
\text { Deviation }\end{array}$ & Average \\
\hline $\operatorname{Age}(\mathrm{Y} / \mathrm{O})$ & & 69,88 & $\pm 8,83$ & \\
\hline \multicolumn{5}{|l|}{ Sex } \\
\hline Male & $27(54 \%)$ & & & \\
\hline Female & $23(46 \%)$ & & & \\
\hline $\begin{array}{l}\text { BedRest-Period } \\
\text { (Days) }\end{array}$ & & 7,00 & & $1-7,30$ \\
\hline GDA (mg/dl) & & 161,18 & $\pm 78,35$ & \\
\hline $\begin{array}{l}\mathrm{LFG}(\mathrm{ml} / \\
\text { menit/1,73 m²) }\end{array}$ & & 56,38 & $\pm 34,25$ & \\
\hline $\mathrm{CRP}(\mathrm{mg} / \mathrm{dl})$ & & 10,5 & & $\begin{array}{l}0,10- \\
390,70\end{array}$ \\
\hline Albumin (mg/dl) & & 2,67 & $\pm 0,65$ & \\
\hline MNA Score & & 13,67 & $\pm 4,56$ & \\
\hline MMSE & & 22,54 & $\pm 3,20$ & \\
\hline Skor ADL & & 8,04 & $\pm 5,69$ & \\
\hline $\begin{array}{l}\text { Intake protein } \\
\text { (gr/24 jam) }\end{array}$ & & 42,98 & $\pm 26,65$ & \\
\hline $\begin{array}{l}\text { UreaNUrin } \\
\text { (gr/24jam) }\end{array}$ & & 4,32 & $\pm 2,61$ & \\
\hline Berat badan $(\mathrm{kg})$ & & 54,92 & $\pm 11,03$ & \\
\hline IMT $\left(\mathrm{kg} / \mathrm{m}^{2}\right)$ & & 21,75 & $\pm 4,33$ & \\
\hline
\end{tabular}

The results of bivariate analysis of various risk factors for negative nitrogen balance vary greatly (Table 2 ). There were 4 factors that showed significant results, i.e., diabetes mellitus, LFG $<90 \mathrm{~mL} / \mathrm{min}$, MNA score $<17$ and duration of bed rest $\geq 7$ days $(p<0.25)$. The other insignificant factors were albumin $<3.5 \mathrm{mg} / \mathrm{dL}$ and $\mathrm{CRP}>6 \mathrm{mg} / \mathrm{dL}$.

The table above shows several eligible risk factors to be continued in the next multivariate analysis of diabetes mellitus, $\mathrm{LFG}<90 \mathrm{~mL} / \mathrm{min}, \mathrm{MNA}<17$ and duration of rest $\geq 7$ days. Furthermore, a logistic regression analysis was conducted to determine the proportion of contributions of each of these risk factors to negative nitrogen balance.

The results of logistic regression analysis on the previous 4 risk factors showed that only glomerular filtration rate $<90 \mathrm{~mL} / \mathrm{min}$ and bed rest $\geq 7$ days had a significant effect on negative nitrogen balance with value $p$ $<0.25$. Glomerular filtration rate $<90 \mathrm{ml} / \mathrm{min}$ has $\mathrm{OR}=5.3$ and bed rest $\geq 7$ days has $\mathrm{OR}=3.63$ (Table 3 ).

Variables of diabetes mellitus and malnutrition were excluded from the analysis because they did not show significant results. The result of logistic regression analysis yields regression model to estimate nitrogen balance as follows: 
$\mathrm{y}=\mathrm{a}+\mathrm{b} 1 \mathrm{x} 1+\mathrm{b} 2 \mathrm{x} 2+\ldots . . \mathrm{bixi}$

$\mathrm{y}=-1.112+1.669\left(\mathrm{LFG}<90 \mathrm{ml} / \mathrm{min} / 1.73 \mathrm{~m}^{2}\right)+1.290$

(duration of bed rest $>7$ days).

With this equation could be predicted the probability of elderly patients experiencing negative nitrogen balance by using the formula: $\mathrm{P}=1 /(1+\mathrm{e}-\mathrm{y})$

$\mathrm{P}=$ probability for negative nitrogen balance $\mathrm{e}=$ natural number $=2.7$

Table 2. The Results of Bivariate Analysis of Risk Factors Affecting Negative Nitrogen Balance

\begin{tabular}{|c|c|c|c|c|c|c|c|}
\hline \multicolumn{2}{|c|}{ Variable } & \multicolumn{2}{|c|}{ Nitrogen Balance } & \multirow[t]{2}{*}{$\mathrm{P}$} & \multirow[t]{2}{*}{ OR } & \multicolumn{2}{|c|}{$\begin{array}{c}\text { Confidence Interval (CI) } \\
95 \%\end{array}$} \\
\hline & & $<-1$ & $\geq-1$ & & & Min & Max \\
\hline \multirow{4}{*}{$\begin{array}{l}\text { Diabetes } \\
\text { Mellitus }\end{array}$} & Yes & 20 & 13 & \multirow{2}{*}{$0.12 *$} & \multirow{2}{*}{0.33} & \multirow{2}{*}{0.08} & \multirow{2}{*}{1.38} \\
\hline & No & 14 & 3 & & & & \\
\hline & GDA $>180$ & 10 & 9 & \multirow{2}{*}{$0.07 *$} & \multirow{2}{*}{0.32} & \multirow{2}{*}{0.94} & \multirow{2}{*}{1.11} \\
\hline & $\mathrm{GDA} \leq 180$ & 24 & 7 & & & & \\
\hline \multirow{2}{*}{$\begin{array}{l}\text { Liver } \\
\text { Function }\end{array}$} & LFG $<90$ & 29 & 8 & \multirow{2}{*}{$0.01 *$} & \multirow{2}{*}{5.8} & \multirow{2}{*}{1.48} & \multirow{2}{*}{22.69} \\
\hline & $\mathrm{LFG} \geq 90$ & 5 & 8 & & & & \\
\hline \multirow{4}{*}{ Nutrition Status } & $\begin{array}{l}\text { MNA }<17 \\
\text { (Malnutrition) }\end{array}$ & 29 & 9 & $0.02 *$ & 4.51 & 1.17 & 17.75 \\
\hline & $\begin{array}{l}\text { MNA } 17-23.5 \text { (At } \\
\text { risk of malnutrition) }\end{array}$ & 5 & 7 & 0.93 & 1.08 & 0.23 & 4.99 \\
\hline & Albumin $<3.5$ & 28 & 13 & 0.93 & 1.08 & 0.23 & 4.99 \\
\hline & Albumin $\geq 3.5$ & 6 & 3 & 0.93 & 1.08 & 0.23 & 4.99 \\
\hline \multirow{2}{*}{ Inflammation } & $\mathrm{CRP}>6$ & 19 & 9 & \multirow{2}{*}{0.98} & \multirow{2}{*}{0.99} & \multirow{2}{*}{0.30} & \multirow{2}{*}{3.26} \\
\hline & $\mathrm{CRP} \leq 6$ & 9 & 7 & & & & \\
\hline \multirow{2}{*}{ Immobility } & Bed Rest Period $\geq 7$ & 24 & 6 & \multirow{2}{*}{$0.03 *$} & \multirow{2}{*}{4.00} & \multirow{2}{*}{1.14} & \multirow{2}{*}{13.95} \\
\hline & Bed Rest Period $<7$ & 10 & 10 & & & & \\
\hline
\end{tabular}

Table 3. The Results of Bivariate Analysis of backward stepwise method

\begin{tabular}{|c|c|c|c|c|c|}
\hline Variable & $\mathrm{B}$ & p-value & Exp. B & \multicolumn{2}{|c|}{ Confidence Interval (CI) 95\% } \\
\hline & & & & Min & Max \\
\hline LFG & 1.669 & 0.02 & 5.3 & 1.27 & 22.13 \\
\hline Immobilty & 1.29 & 0.05 & 3.63 & 0.95 & 13.82 \\
\hline Constant & -1.112 & 0.11 & 0.33 & & \\
\hline
\end{tabular}

\section{DISCUSSION}

The aging process results in changes of body composition and organ function. In addition, there was a change in the ability to obtain food, immobility, insulin resistance, chronic diseases, etc (Ahmed and Haboubi, 2010, Kagansky et al., 2005, Saka et al., 2010). Research conducted by Babineau et al., (2008), that about $60 \%$ of elderly patients treated in hospital were malnourished (Babineau et al., 2008).

In this study, the most significant risk factors were renal function impairment ( $\mathrm{LFG}<90 \mathrm{mil} / \mathrm{min} / 1.73 \mathrm{~m} 2)$ and duration of bed rest $>7$ days that affecting negative nitrogen balance in elderly patients who undergoing hospitalization. The occurrence of a negative nitrogen balance in LFG $<90 \mathrm{~mL} / \mathrm{min}$ was due to the limitation of protein intake in patients with chronic kidney disease. In addition, there will be an inflammatory process that will increase protein catabolism when the kidney function decreases (Cano et al., 2006, Ganesan et al., 2009, Carrero et al., 2013).

The research conducted by Sawe et al (2012) in 38 patients aged 40-60 years who had chronic renal failure pradialysis, it was found that patients with $\mathrm{LFG}<15 \mathrm{ml} /$ $\mathrm{min} / 1.73 \mathrm{~m}^{2}$ had more negative nitrogen balance than patients with LFG $15-60 \mathrm{ml} / \mathrm{min} / 1.73 \mathrm{~m}^{2}$. PGK patients with protein intake $<0.75 \mathrm{gr} / \mathrm{kgbb} /$ day showed a more negative nitrogen balance than the group with protein intake $>0.75 \mathrm{gr} / \mathrm{kgbb} /$ day. Patients with $\mathrm{LFG}<15 \mathrm{ml} / \mathrm{min} / 1.73 \mathrm{~m}^{2}$ who consumed lower proteins all gave a negative nitrogen balance (Sawe et al., 2012).

The occurrence of negative nitrogen balance on the risk factor of bed resting $>7$ days caused by the patient with the duration of bed rest $>7$ days on average was the patient with chronic disease, so the longer bed rest then show the longer recovery period followed by the process of catabolism high. 
Research conducted by Ferrando et al (1996), Teasell and Dittmer (1993) showed that immobility could cause nitrogen loss from the body after 2 weeks of bed rest because of increased the protein catabolism along with decreased protein synthesis, exacerbated by starvation, trauma, infection, or inflammation in resulting to achieve nitrogen loss (12 to 10 grams/day) (Ferrando et al., 1996, Teasell and Dittmer, 1993).

Another study from Rousseau (1993), that immobility for 7 days will increase urinary nitrogen excretion. This loss of nitrogen could reach $2 \mathrm{~g}$ /day and reach the peak in the second week of immobility. It was also exacerbated by decreased appetite, decreased intestinal absorption and constipation resulting in decreased protein synthesis (Rousseau, 1993).

The weakness in this research was cross-sectional research design with one time data taking so it could not accurately describe the causal relationship. In addition, in this study were not done yet for the measurement of nitrogen in the blood so that the actual balance of nitrogen could not be assessed. Another disadvantage was the presence of other diseases not excluded in this study that might be affect the balance of nitrogen.

\section{CONCLUSION}

The decreased of renal function with LFG $<90$ $\mathrm{mL} / \mathrm{min}$ and immobilization with bed rest $>7$ days was showed as the most significant risk factor for protein malnutrition in elderly patients.

\section{CONFLICT OF INTEREST}

The authors declare there is no conflict of interest.

\section{REFERENCES}

Ahmed, T. \& Haboubi, N. 2010. Assessment And Management Of Nutrition In Older People And Its Importance To Health. Clinical Interventions In Aging, 5, 207.

Babineau, J., Villalon, L., Laporte, M. \& Payette, H. 2008. Outcomes Of Screening And Nutritional Intervention Among Older Adults In Healthcare Facilities. Canadian Journal Of Dietetic Practice And Research, 69, 91-96.

Brownie, S. 2006. Why Are Elderly Individuals At Risk Of Nutritional Deficiency? International Journal Of Nursing Practice, 12, 110-118.

Cano, N., Fiaccadori, E., Tesinsky, P., Toigo, G., Druml, W., Kuhlmann, M., Mann, H. \& Hörl, W. 2006. Espen Guidelines On Enteral Nutrition: Adult Renal Failure. Clinical Nutrition, 25, 295-310.

Carrero, J. J., Stenvinkel, P., Cuppari, L., Ikizler, T. A., KalantarZadeh, K., Kaysen, G., Mitch, W. E., Price, S. R., Wanner, C. \& Wang, A. Y. 2013. Etiology Of The Protein-Energy Wasting Syndrome In Chronic Kidney Disease: A Consensus Statement From The International Society Of Renal Nutrition And Metabolism (Isrnm). Journal Of Renal Nutrition, 23, 77-90.

Epel, E. S. 2009. Psychological And Metabolic Stress: A Recipe For Accelerated Cellular Aging. Hormones (Athens), 8, $7-22$.

Ferrando, A. A., Lane, H. W., Stuart, C. A., Davis-Street, J. \& Wolfe, R. R. 1996. Prolonged Bed Rest Decreases Skeletal Muscle And Whole Body Protein Synthesis. American Journal Of Physiology-Endocrinology And
Metabolism, 270, E627-E633.

Ganesan, M. V., Annigeri, R. A., Shankar, B., Rao, B. S., Prakash, K. C., Seshadri, R. \& Mani, M. K. 2009. The Protein Equivalent Of Nitrogen Appearance In Critically Ill Acute Renal Failure Patients Undergoing Continuous Renal Replacement Therapy. Journal of Renal Nutrition, 19, 161-166.

Kagansky, N., Berner, Y., Koren-Morag, N., Perelman, L., Knobler, H. \& Levy, S. 2005. Poor Nutritional Habits Are Predictors Of Poor Outcome In Very Old Hospitalized Patients. The American Journal of Clinical Nutrition, 82, 784-791.

Kurpad, A. \& Vaz, M. 2000. Protein And Amino Acid Requirements In The Elderly. European Journal of Clinical Nutrition, 54, S131.

Lieberman, M., Marks, A. D., Smith, C. M. \& Marks, D. B. 2007. Biokimia Kedokteran Dasar, Jakarta, Penerbit Buku Kedokteran Egc.

Morais, J., Chevalier, S. \& Gougeon, R. 2006. Protein Turnover And Requirements In The Healthy And Frail Elderly. The Journal Of Nutrition, Health \& Aging, 10, 272.

Musso, C. G. \& Núñez, J. F. M. 2006. Feed-Back Between Geriatric Syndromes: General System Theory In Geriatrics. Springer.

Pannemans, D. L., Wagenmakers, A. J., Westerterp, K. R., Schaafsma, G. \& Halliday, D. 1997. The Effect Of An Increase Of Protein Intake On Whole-Body Protein Turnover In Elderly Women Is Tracer Dependent. The Journal Of Nutrition, 127, 1788-1794.

Rousseau, P. 1993. Immobility In The Aged. Archives Of Family Medicine, 2, 169.

Rubenstein, L. Z., Harker, J. O., Salvà, A., Guigoz, Y. \& Vellas, B. 2001. Screening For Undernutrition In Geriatric Practice: Developing The Short-Form Mini-Nutritional Assessment (Mna-Sf). The Journals Of Gerontology Series A: Biological Sciences And Medical Sciences, 56, M366-M372.

Saka, B., Kaya, O., Ozturk, G. B., Erten, N. \& Karan, M. A. 2010. Malnutrition in the Elderly and its Relationship with other Geriatric Syndromes. Clinical nutrition, 29, 745748 .

Sawe, N., As'ad, S. \& Satriono R. 2012. Korelasi Diet Rendah Protein terhadap Keseimbangan Nitrogen pada Pasien Penyakit Ginjal Kronik. Universitas Hasanuddin Makasar, 1 - 12.

Smil. V. 2002. Nitrogen and food production: proteins for human diets. AMBIO: A Journal of the Human Environment, $31,126-131$.

Smoliner, C., Norman, K., Scheufele, R., Hartig, W., Pirlich, M. \& Lochs, H. 2008. Effects of food fortification on nutritional and functional status in frail elderly nursing home residents at risk of malnutrition. Nutrition, 24, 1139-1144.

Teasell, R. \& Dittmer, D. 1993. Complications of immobilization and bed rest. Part 2: Other complications. Canadian Family Physician, 39, 1440. 